\title{
THE DARK SIDE OF POWER: THE DARK TRIAD IN OPPORTUNISTIC DECISION-MAKING'
}

\author{
Márcia Figueredo D'Souza ${ }^{2}$ \\ Gerlado Augusto Sampaio Franco de Lima ${ }^{3}$
}

\begin{abstract}
This study promotes an analysis of the influence of personality traits of the Dark Triad in the process of opportunistic decision-making. The Dark Triad is a constellation that includes three non-pathological personality traits: Narcissism, Psychopathy and Machiavellianism. The triad, although conceptually distinct, has empirically externalized overlapping features in individuals by the tendency for self-promoting behavior, emotional coldness, duplicity, aggression and socially evil character. Considering that personality traits have significant implications with regard to judgment and opportunistic decision-making, this research aims at the effective dialogue of ideas proposed here. The theoretical empirical study was elected via a self-report questionnaire, applied with 131 MBA students. Through the descriptive statistics, factor analysis, correlations and the one-way ANOVA methods, we find that there is significant relationship between the high traits of the Dark Triad and the opportunistic decision-making, and the existence of a difference between levels (low, moderate and high) of the Dark Triad in opportunistic decision-making. Considering the presented results, this study achieved the desired goal, validated the elaborated assumptions and drew the attention of the scientific community to the potential of the Dark Triad in the business field, especially by observing the behavior of managers in the work environment. We highlight the importance of this research in the national context, since most studies, which address this theme, developed individualized investigations with the personality traits that make up the constellation Dark Triad.
\end{abstract}

Keywords: Dark Triad. Opportunistic Decision-making. Accounting

\footnotetext{
Artigo aprovado e apresentado no EnAnpad 2014

E-mail: marciafdsouza@yahoo.com.br. UNEB - Universidade do Estado da Bahia.

${ }^{3}$ E-mail: gerlandolima@gmail.com. USP - Universidade de São Paulo.

- DOI: http://dx.doi.org/10.14392/asaa.2015080201

- Artigo recebido em: 16/04/2015. Revisões requeridas: 01/08/2015. Aprovado em: 18/08/2015.
} 


\section{O LADO SOMBRIO DO PODER: O DARK TRIAD NA TOMADA DE DECISÃO OPORTUNISTA}

Resumo: Este estudo promove uma análise da influência dos traços de personalidade do Dark Triad na tomada de decisões oportunista. O Dark Triad é uma constelação que inclui três traços de personalidade, não patológicos: Narcisismo, Psicopatia e Maquiavelismo. A tríade, embora conceitualmente distinta, empiricamente possui características sobrepostas exteriorizadas nos indivíduos pela tendência ao comportamento para a autopromoção, frieza emocional, duplicidade, agressividade e um caráter socialmente maléfico. Considerando-se que os traços de personalidade têm implicações significativas no que diz respeito ao julgamento e tomada de decisão oportunistas, esta pesquisa visa o diálogo eficaz das ideias aqui propostas. $O$ estudo empírico teórico foi eleito através de um questionário de auto-relato, aplicado com 131 estudantes de MBA. Pelos métodos estatísticos Descritivo, Análise Fatorial, Correlacional e ANOVA de um fator, constatou-se relação significativa entre os altos traços do Dark Triad e a tomada de decisão oportunista e a existência de diferença entre os níveis (baixo, moderado e alto) do Dark Triad na tomada de decisão oportunista. Diante dos resultados apresentados, o presente estudo alcançou o objetivo almejado, validou as suposições elaboradas e sinaliza a atenção da comunidade científica para a potencialidade do Dark Triad na área de negócios. Cabe ressaltar a importância desta pesquisa no contexto nacional, visto que a maioria dos estudos os quais abordam essa temática desenvolveu investigações individualizadas com os traços de personalidade que compõem a constelação Dark Triad.

Palavras-chave: Dark Triad. Tomada de decisão oportunista. Contabilidade. 


\section{INTRODUCTION}

The ethical environment of the company is, in fact, defined by the actions of top executives, especially the CEOs (Rijsenbilt \& Commandeur, 2013), who exert, with significant influence, the power over countless policies that underlie the preparation of financial statements of their companies. They utilize accounting information as a means to express both the operational and personal performances, given that the accounting-based performance goals help set the bonus and the reward system (Amernic \& Craig, 2010).

Studies relate the behavior of business leaders to personality traits (Maccoby, 2004; Rosenthal \& Pittinsky, 2006; Chatterjee \& Hambrick, 2007; Babiak, Neumann \& Hare, 2010; Jain \& Bearden, 2011), by the evidence of direct influence on leadership skills of the individual, team performance and overall organizational effectiveness (Hogan, 2007). However, Judge, Piccolo and Kosalka (2009) point out that a personality can either be socially desirable or undesirable or influence positive and/or negative behaviors in the organizational context.

Instigated to meet dark personality features, Paulhus and Williams (2002) empirically tested non-pathological traits of narcissism, Machiavellianism and psychopathy, named by the authors as the Dark Triad. The triad, although conceptually distinct, has empirically externalized overlapping features in individuals by the tendency for self-promoting behavior, emotional coldness, duplicity, aggression and socially evil character.

It is important to point out that non-pathological or subclinical personality traits are detectable in individuals who are not involved in prison or forensic offenses, in order to capture trends and dispositions towards certain behaviors, through a self-report questionnaire (Patrick 2010), without the intention of verifying personality disorders that demonstrate psychiatric diagnoses (Furnham, Richards \& Paulhus, 2013).

The Dark Triad traits have been studied - individually or jointly-related - in the business world, in order to check the characteristics related to fraud motivation in financial reports (Johnson, Kuhn, Apostolou \& Hassell, 2013; Murphy, 2012), the excessive confidence and risk in decision-making (W. K. Campbell, Goodie \& Foster, 2004; Jain \& Bearden, 2011; Lakey, Rose, W. K. Campbell \& Goodie, 2008), the decision-making of capital investments, Dworkis (2013); the risky decisions motivated by impulsive behavior (Crysel, Crosier, Webster \& Gregory, 2013); to making selfish decisions (Judge et al., 2009); the authoritarian style of decision-making (Maleki, 2013); the management of operating results (Shafer \& Wang, 2011); betting with the money of others for personal gain (Jones, 2013); and counterproductive behavior in the workplace (O'Boyle, Forsyth, Banks \& McDaniel, 2012; Spain Harms \& Lebreton, 2014).

The decision-making in the disposition to fraud and manipulation of operating results has drawn the attention of the scientific community, especially after the financial scandals in the business world. In this context, the present study unfolds from the following question: are individuals with high personality traits of the Dark Triad predisposed to making opportunistic decisions? To this end, we intend to analyze the influence of personality traits of the Dark Triad in the process of opportunistic decision-making.

Furthermore, the findings of the presented studies support the premise that individuals with high personality traits of the Dark Triad are prone to decide in an opportunistic way. In this conception, the Upper Echelons Theory, whose central assumption states that the personalities, values and experiences 
of executives strongly influence their interpretations, which, in turn, affect their choices (Hambrick and Mason, 1984), is the theory underlying this research.

We highlight the importance of this research in the national context, since most studies, which address this theme, developed individualized investigations with the personality traits that make up the constellation Dark Triad. In addition, the aversive behavior externalized by individuals who possess these traits, as identified in the business environment, may minimize unethical actions that affect business continuity in the long term and all those interested in business success.

The empirical results of this study suggest a significant relationship between high traits of the Dark Triad and handling business results as well as the existence of differences between levels (low, moderate and high) of the Dark Triad in opportunistic decision-making.

In this sense, the subsequent sections present a literature grounded in scientific works, an empirical-theoretical-methodological approach, with quantitative design aiming to respond to the research question and test the hypotheses, followed by the analysis of the results and conclusions of the investigation.

\section{THEORETICAL BACKGROUND 2.1 Conceptual aspects of the Dark Triad}

The American Psychological Association defines personality "[...] as a configuration of traits and behaviors which includes the only adjustment of an individual to life, including traits, impulses, interests, values, self-concept, important capabilities and emotional patterns" (VandenBos, 2010, p. 701). According to Cervone and Pervin (2008, p.8), personalities "are psychological qualities that contribute to one's enduring and distinct feeling, thinking and behaving patterns." From this perspective, personality is more than behavior. It refers to the way one thinks, feels and perceives the world (Hurst \& Jung, n.d).

One's conduct can be summarized, explained and predicted by personality traits, defined as "[...], relatively stable, consistent and permanent internal characteristics which are deducted from his pattern of behavior, attitudes, feelings and habits "(VandenBos 2010, p. 701).

Paulhus and Williams (2002) developed a study on the subclinical personality traits, considered socially aversive, of narcissism, Machiavellianism and Psychopathy, called Dark Triad. To this end, these authors applied a self-report questionnaire type with 245 university psychology students (65\% women). Initially, the triad was individually mapped to the domains of the Big Five (extraversion, agreeableness, consciousness, neuroticism and openness), in order to analyze the similarities and differences in relation to the fundamental dimensions of personality. Sequentially, it was compared to the measures of cognitive ability. The measurements presented were moderately intercorrelated. The Big Five factors were associated with one or more of the Dark Triad variables, whose remarkable similarity of the triad was the lack of affability.

The authors concluded that although conceptually distinct, the traits of narcissism, Machiavellianism and psychopathy show empirically overlapping features, externalized by "[...] a socially malevolent 
character with behavior tendencies toward self-promotion, emotional coldness, duplicity, and aggressiveness" (Paulhus \& Williams, 2002, p. 557).

The findings of the study resulted in a psychological aspects measuring instrument, termed now as a Short Dark Triad (SD3), which is composed of 27 assertions, nine assertions for each trait. Four studies with 1,063 people (students and community) were needed to measure the reliability and validity of the instrument directed to the empirical application in normal populations (Jones \& Paulhus, 2014).

In addition, these studies are not in the pathological sphere. In other words, they neither care about the personality disorder treated by psychiatry nor the legal sphere. According to Patrick (2010), subclinical traits differentiate from the clinical features, because they are targeted to individuals who are not involved in prison or forensic infractions, whose development aims to capture trends available for a particular behavior, through a self-report questionnaire consisting of - "statements or series of questions provided by a person as to his condition, feeling or belief" - (VandenBos 2010, p. 701).

In contrast, the clinical features are assessed by a check-list, in semi-structured interviews and prison files, in order to obtain additional information, so to compare to the results of the interviews. Such assessments are directed to more efficient clinical diagnosis in high-risk communities and adolescent offenders (Patrick 2010).

\subsection{Characteristics of the personality traits of the Dark Triad in the business environment 2.2.1 Narcissism}

The term derives from the legend of Narcissus, who took his image as someone else, fell in love with her and died when she stopped loving him (Levy, Reynoso, Wasserman \& Clarkin, 2010).

Individuals with traits of narcissism externalize "excessive self-love or self-centeredness" (VandenBos 2010, p. 635) and usually present "[...] a pervasive pattern of grandiosity, need for admiration and lack of empathy" (American Psychiatric Association, 2000).

Socially, narcissistic individuals are selfish, exaggerated when showing off their own talents and skills, charming, outgoing, need attention and power to be able, and demonstrate a pervasive pattern of grandiosity (Arjoon, 2010); they are arrogant, have a sense of entitlement, low self-esteem, self-absorption, hostility and are motivated by the need for power and admiration (Rosenthal \& Pittinsky, 2006).

In the business world, individuals with narcissistic traits are visionary, charismatic, and seek positions of power, leadership and influence over people. They reflect an image that approaches the conception of great leaders because they are convincing and hold business vision and ability to attract followers. They are innovative and lead the business to gain power and glory (Maccoby, 2004; Rosenthal \&Pittinsky, 2006; Chatterjee \&Hambrick, 2007).

Narcissistic leaders are more likely to interpret the information with a bias of self-interest and make decisions based on how those decisions will reflect on their reputations (Judge et al., 2009). They are concerned with controlling others and may become paranoid, as it pertains to perceived enemies, especially when they are under excessive stress (Maccoby, 2004, p. 3). They have a positive and significant relationship with the authoritarian style of decision-making and maintain an inverse relationship with the style of participatory decision-making (Maleki, 2013). 
However, self-confidence, sense of grandeur, exploitation and persistence may, under certain circumstances, also make them successful in the organizational environment (O'Reilly, Doerr, Chatman \& Caldwell, 2013), with a trend towards effective leadership (Rosenthal \& Pittinsky, 2006).

Psychopathy is a personality trait marked by “[...] egocentrism, impulsivity, lack of emotions such as guilt and remorse [...]" (VandenBos 2010, p. 764). Individuals with this trait have the ability to influence and dominate others, demonstrate low anxiety, take risks to seek thrills in danger, are reckless, selfish, aggressive, profiteers, insensitive, always blames others, see themselves as victims, are oriented to the present, act without planning and have low imaginative capacity (Patrick, 2010).

In the business area, most corporate managers, occupants of senior executive positions, have no pathological traits of psychopathy. This evidence was found in a group of 203 business professionals, which showed a positive association with charisma, presentation style (creativity, strategic thinking and good communication skills) and a negative association with measures of accountability and performance (Babiak et al., 2010).

Corporate psychopaths manage organizations by power, money and prestige, and are concerned with the exclusion of others. They are indifferent to the fate of the organizations for which they work or their coworkers (Babiak and Hare, 2006; Boddy, 2010). They are opportunistic, self-centered, cruel and cynical people; however, they can be charming, manipulative and ambitious. They threaten the performance and longevity of the business, for putting their interests above the interests of the company. Moreover, the sense of social responsibility of the business is threatened, because they have no sense of guilt, shame or remorse over the consequences of their decisions. The businesses attract them for being sources of power, prestige and money (Boddy, 2005).

Empirical studies linking psychopathy to leadership reveal positive and negative aspects of the characteristics of this trait. On the one hand, the fearless dominance observed in psychopathic individuals can positively influence overall job performance and successful communication; on the other hand, the egocentric impulsivity can result in unethical behavior, leading to ineffective styles (Smith \& Lilienfeld, 2013).

\subsubsection{Psychopathy}

Psychopathy is a personality trait marked by "[...] egocentrism, impulsivity, lack of emotions such as guilt and remorse [...]" (VandenBos 2010, p. 764). Individuals with this trait have the ability to influence and dominate others, demonstrate low anxiety, take risks to seek thrills in danger, are reckless, selfish, aggressive, profiteers, insensitive, always blames others, see themselves as victims, are oriented to the present, act without planning and have low imaginative capacity (Patrick, 2010).

In the business area, most corporate managers, occupants of senior executive positions, have no pathological traits of psychopathy. This evidence was found in a group of 203 business professionals, which showed a positive association with charisma, presentation style (creativity, strategic thinking and good communication skills) and a negative association with measures of accountability and performance (Babiak et al., 2010).

Corporate psychopaths manage organizations by power, money and prestige, and are concerned with the exclusion of others. They are indifferent to the fate of the organizations for which they work or their coworkers (Babiak and Hare, 2006; Boddy, 2010). They are opportunistic, self-centered, cruel and 
cynical people; however, they can be charming, manipulative and ambitious. They threaten the performance and longevity of the business, for putting their interests above the interests of the company. Moreover, the sense of social responsibility of the business is threatened, because they have no sense of guilt, shame or remorse over the consequences of their decisions. The businesses attract them for being sources of power, prestige and money (Boddy, 2005).

Empirical studies linking psychopathy to leadership reveal positive and negative aspects of the characteristics of this trait. On the one hand, the fearless dominance observed in psychopathic individuals can positively influence overall job performance and successful communication; on the other hand, the egocentric impulsivity can result in unethical behavior, leading to ineffective styles (Smith \& Lilienfeld, 2013).

\subsubsection{Machiavellianism}

Machiavellianism is a personality trait characterized by a "[...] calculating attitude towards human relationships and a belief that the end justifies the means, but it is inhuman" (VandenBos 2010, p. 574). This personality trait was labeled to reflect the philosophy of Niccolo Machiavelli, a political advisor to the Medici family in the fifteenth century (Furnham et al., 2013), who saw people "[...] more or less as objects to be manipulated in the pursuit of his goals, if necessary, through deliberate fraud ", so that an effective ruler should be prepared to do so (VandenBos 2010, p. 574).

Christie and Geis (1970) developed a personality inventory to measure the traits, based on the original writings of Machiavelli and, when empirically applied in individuals, resulted in cynical and unprincipled attitudes, whose main belief is that the interpersonal handling is the key to success in life.

In the organizational environment, individuals with Machiavellian traits assume positions of management and leadership, seeking to manage business by which they can manipulate and control others (Fehr, Samsom \& Paulhus, 1992; Corzine, 1997; Judge et al, 2009.). They are politically driven to seek control over followers (Mchoskey, 1999). They use impressive management tactics and have a natural talent for influencing people (Goldberg, 1999). These leaders are less willing to adhere to procedures or to seek high standards of ethics and morality, by focusing on their own personal power (Judge et al., 2009, p. 867).

Individuals with Machiavellian traits tend to make management decision of results (Shafer \& Wang, 2011), deceive and defraud financial reports (Murphy, 2012), mask budget headings (Byington \& Johnson, 1990) and demonstrate abusive supervision and authoritarian leadership (Kiazada, Restubog, Zagenczyk, Kiewitz, \& Tang, 2010). When they are under pressure, they tend to create budgetary slack (Hartmann \& Maas, 2010) and are more successful (Aziz 2002).

By relating the trait of Machiavellianism with overconfidence, Jain and Bearden (2011) found that Machiavellian individuals generate the expectation of owning a performance superior to others, although they submitted worse and minor performance gain compared with non-Machiavellian individuals.

\subsection{Judgment and Decision-making 2.3.1 Conceptual and theoretical aspects}

Judgment refers to the formation of an idea, opinion or estimate of an object, an event, a state or other phenomenon. Decisions follow judgments and involve a choice among several alternatives whose 
preference is shown as a function of factors such as risk and money. Judgment reflects opinions, while decisions reflect opinions and preferences (Bonner, 2007).

The ideal decision-making - within the perspective of the Normative Theory, which proposes Unlimited Rationality - is based on mathematical and statistical calculations needed to precisely review the values and preferences of the risks of decision makers (Bazerman \& Moore, 2010). This theory grants the economic man the maximizing of his individual utility and the choosing of the best alternative in a context of full knowledge of the possible states of the world, whose rationality gives him the knowledge of how to make choices, so to maximize something (Edwards, 1954).

On the other hand, the Descriptive Theory proposes bounded rationality and satisfactory resolution of problems in order to achieve an acceptable minimum. It is proposed by Simon (1970) and argues that, when making the decision, the manager does not take into account all possible alternatives, but those which he thinks will maximize gain and minimize loss (Sternberg , 2009, p. 432). The individual has only a fragmentary knowledge, with slight perceptions of the regularities of the observed phenomenon, with limited alternatives, due to time, resources and other restrictions. The rational behavior lacks psychological aspects such as perception, thinking and learning (Simon, 1970).

With the purpose of investigating the psychological, subjective and emotional aspects involved in decision strategies, Kahneman and Tversky (1974), based on the Theory of Limited Rationality, observed through empirical experiments that individuals, when making decisions, use mental shortcuts which, sometimes, lead to biases in judgment. Mental shortcuts, also called heuristics, are present in judgments under uncertainty and closely related to the cognitive and behavioral process of decision-making. These shortcuts have been studied by Kahneman and Tversky (1974), theorists that give a simplified strategy of judgment in the decision process.

Hambrick and Mason (1984) developed a study that culminated in the Upper Echelons Theory, whose central idea was presented in two interconnected parts: 1) executives act based on their personalized interpretations in the light of strategic situations and 2) these customized interpretations are processed based on the executives' experience, values and personalities. The study is grounded on the assumption of bounded rationality, in which situations of uncertainty are not objectively "knowable", but are rather interpretable.

\subsubsection{The opportunistic decision-making}

According to Limited Rationality Theory, managers seek a satisfactory solution to reach business goals and personal interests and, sometimes, face the dilema of opportunistically using the accounting information in managerial decision-making. Mohanram (2003) stresses that managers make use of accounting information to cheat on those most interested in the operational results. In this regard, information is intentionally and voluntarily distorted, with the adoption of procedures that conflicts with the law and accounting standards, characterizing fraud (Beneish 2001).

However, business decisions may also be made with the observation of accounting patterns and policies, especially the change of accounting criteria, which is possible due to the flexibility of accounting norms and standards (Stolowy \& Breton, 2004). Mohanram (2003) states that in this perspective it is difficult to perceive if such changes represent opportunistic manipulation or just a discretionary accounting choice. 
Examining how the biggest scammers in history (Madof; Carlo Ponzi, in the case of the pyramid; Kenneth Lay at Enron, among others) have deceived so many for so long, Nars (2012) presents seven possible financial "maneuvers" - discussed by Schilit and Perler (2010) and published by the Center for Financial Research \& Analysis- used for fraudulent companies to mislead investors, tax authorities, banks and other interest groups, in order to create a positive image of financial business situation:

1 - Register profits prematurely or those of questionable quality (+);

2 - Register false profits (+);

3 - Strengthen revenue gains in a single operation (+);

4 - Transfer current expenditure to a previous or future period (+ or -);

5 - Failure to improperly register or reduce future liabilities (+);

6 - Transfer current income for a future period (-);

7 - Transfer future expenses to the current period with a cost differential;

$(+)=$ Improves the company's profit numbers;

$(-)=$ Reduces the profit figures in order to create reserves for the future or reduce taxes (Nars, 2012, pp. 30-31).

The author argues that other techniques may also be used, such as the absence of facts recorded in the accounting reports or use of bills, statements or false services.

The perspective of the opportunistic manager was chosen for this study, given the practical difficulty of establishing the limit between the management that is in accordance with or conflicting with the standards as states Scott (2009, p. 424) "(...) the accountant steps on a thin line between the management of results and the bad management of gains."

\subsection{Traits of the Dark Triad: motivating the opportunistic decision-making?}

Personality traits in managers have significant implications with regard to judgment and decision making, especially by overconfidence in managerial skills. Risky and impulsive decisions are attributes of managers with narcissistic traits, by focusing on short term goals without concern for the long-term consequences. Just as these decisions may be beneficial for the organization and for the image of these managers, they may also prove equally destructive (W. K. Campbell, Hoffman, S. M. Campbell \& Marchisio, 2011).

As the corporate officer holds the highest position in the corporate hierarchy, he can define and influence ethical or unethical decisions. Furthermore, the results of financial accounting are a personal demonstration of his success or failure. Many CEOs consider the performance measures of financial accounting as indicative of personal accomplishment. Moreover, the periodic nature of the publication of financial reports provides the need for applause for the narcissistic managers (Amernic \& Craig, 2010).

Olsen, Young e Dworkis (2013) state that earning per share (EPS), being the most expressive and visible result of accounting, sometimes is managed (or not) in a discretionary way, due to the choices of estimates and accounting policies made by the CEO with the intention of reflecting his or her perfor- 
mance. The higher the EPS, the higher the quantity of compliments and praise, needed to support the inflated sense of self-importance presented by individuals with predisposition to narcissistic behavior.

Rijsenbilt and Commandeur (2013) found a positive and statistically significant relationship between narcissism in CEOs and the occurrence of fraud. 54 CEOs with three years in office were selected from the S\&P 500 CEOs' database from 1992 to 2008, and had their companies' related managerial fraud disclosed by the Securities Exchange Commission (SEC). Highly narcissistic CEOs can achieve greatness for their companies; however, if there is no control, it may result in unethical behavior and harm the interests of the organization.

If CEOs are extremely narcissistic and control the communication activities and governance associated with the accounts, it can be inferred that the examination of the interaction between accounting and narcissistic behavior emerges. The possibility of manipulation and malicious interpretation of the actual construction of accounting information occurs as narcissistic purpose. CEOs strongly influence the underlying policies of the performance measures of financial accounting, since sometimes their personal remuneration depends directly and indirectly on such measures (Amernic \& Craig, 2010).

Johnson et al. (2013) set out to examine the perceptions of auditors about narcissistic characteristics of managers-clients and the motivation for fraudulent attitudes. The results showed that the narcissistic behavior of managers and their predisposition to fraud are significant and are positively related to the assessment of fraud risk.

When it comes to analyzing managers' decisions concerning psychopathic traits, without the inhibitory effect of consciousness, corporate psychopaths are able to lie, persuade and manipulate in pursuit of their main goals of power, wealth and status. They may be responsible for much of the misbehavior, including accounting fraud, stock manipulation, unemployment and environmental damage due to the lack of social responsibility (Boddy, 2006). Psychopaths are willing to falsify financial results for promotion (McCormick and Burch, 2005), bonus, and other benefits and even commit outright fraud (Clarke, 2005) about the company that employs them.

Moreover, the organizational chaos provides the necessary stimulus and fertile ground for corporate psychopaths to satisfy their behavior in seeking excitement, creating opportunities for manipulation and abuse of power. Often factors such as the absence of institutionalized rules or formal limits in the prerogatives of the leaders; abstract goals; strict control on the movement of information systems; and the reward of the increased value of profits and stock prices allow, to some degree, the devious behavior of the corporate psychopaths, giving them the freedom to conduct destructive and manipulative leadership (Deutschman, 2005; Ouimet, 2010). However, as Pech and Slade (2007) point out, if these executives meet corporate business objectives, the attention to these negative trends may be neglected.

Similar to narcissistic and psychopathic traits, managers with traits of Machiavellianism tend to make opportunistic decisions. Murphy (2012) investigated rationalization, as one of the three characteristics that make up the fraud triangle (opportunity, pressure and rationalization), relating it to the trait of Machiavellianism, and proved that this relationship implies the existence of misrepresentation in financial reports. Shafer and Wang (2011) found the relationship between Machiavellian traits and the decision-making of results' management. Byington and Johnson (1990) demonstrated the tendency of Machiavellian individuals toward handling budget line items.

The findings of this study contribute to reinforce the belief that dark personality traits encourage opportunistic decision-making which provides benefits to managers to the detriment of business interests. 


\section{METHODOLOGY 3.1 Hypotheses and method}

The research methodology adopted the empirical-theoretical approach. The survey was used as a strategy to respond to the research issue and identify the relationship between the study variables, especially for describing and comparing behaviors, opinions and attitudes.

The quantitative design is applied in order to test the following statistical hypotheses:

$\mathrm{H} 1$ : There is significant difference between the levels (low, moderate and high) of the Dark Triad in opportunistic decision-making.

$\mathrm{H} 2$ : There is significant relationship between the high traits of the Dark Triad and the opportunistic decision-making.

In order to check these hypotheses, the following statistical techniques were applied: Descriptive, Factor Analysis, Correlation and the one-way ANOVA. The descriptive statistical and the correlation techniques were selected with the aim of verifying the relationship between the Dark Triad and opportunistic decision-making and are in line with the statistical procedures used to prepare the instrument for the psychological measuring of Paulhus and Williams (2002) and Jones and Paulhus (2014), which is the basis for this investigation.

Additionally, in order to observe whether there are differences between the decision-making behaviors in each personality trait, we used the one-way ANOVA hypothesis test of differences in averages, given the nature of the variables (independent- qualitative and dependent - quantitative) involved in the research, notes Field (2009).

\subsection{Data collection technique}

We adopt the questionnaire as a technique for data collection, whose production was based on hypothetical situations, in order to verify attitudes and behaviors in a business context. The questionnaire was structured in four parts highlighted below:

- Part 1:Terms of informed consent explaining the guarantee of freedom to the research participant to refuse to participate or withdraw his consent at any stage of the research, without any penalty, besides ensuring confidentiality and privacy during all phases of the research.

- Part 2: Demographic profile.

- Part 3: 27 assertions of the measuring instrument of psychological aspects (D3-Short- Paulhus, 2013).

- Part 4: 10 assertions in decision-making practices, among which are seven questions with content contextualized in "financial maneuvers" presented by Nairs (2010), in an attempt to show a predisposition to opportunistic decision-making. The other three questions were prepared with different content, interspersed with the others, to divert the surveyed object of study, similarly to the investigation of Murphy (2012).

For the parameterization on the opportunistic (or not) decision-making, the sample was divided by the average and figures above the average were considered with predisposition to opportunistic decision-making and the figures below the average with no predisposition to opportunistic decision-making. 
The hypothetical situations were initially contextualized, and the surveyed ones received an incentive, such as variable remuneration, intended to detect when they are encouraged to manipulate the results or not.

\subsection{Operationalization of the psychological measurement instrument}

The D3-Short contains 27 assertions, nine for each personality trait, whose measurement of personality traits is nurtured by the Likert (1-5) scale.

In the present study, we run a factor analysis between the three traits and found one factor by the regression output. This factor represents the Dark Triad characteristic between the three traits. The Bartlett's Test is significant $\quad(p<0.01)$ and the KMO is approximately 0.6 .

To determine the high, moderate and low level of traits, the tercile of the found factor were calculated.

Considering that the instrument was made outside the US, we required the authors' permission to apply it in Brazil and also submitted a reverse translation to seven judges (professors): 1) three professionals translated it into Portuguese; 2) these translations were forwarded to other three professionals who then translated these versions into English; and 3) finally, the six translations were validated by another judge with expertise in the psychological field.

\subsection{Survey sample}

The survey was conducted with 131 MBA students. The institution and students were selected because they were a group composed by students who hold and has already held managerial positions, able to make operational decisions, on investment and financing, with the use of accounting information, in contexts of business simulation.

Furthermore, most of the referenced international studies (Major, 2014; Lakey et al, 2008; Paulhus \& Williams, 2002; Paulhus \& Jones, 2014; W. K. Campbell et al, 2004, among others) used college students as audience for the application of the research due to the achievement of consistent results when compared with the research applied with professionals.

The investigated sample had the following demographic profile: Gender (64,1\% males); Age (13\% aged between 18 and 25 years, 65,6\% between 26 and 35 years, 18,3\% between 36 and 45 and 3,1\% aged 46 years old and above); and, all of them are working at this moment and have just assumed a managerial position in the company.

It is noteworthy that, under the criteria of sample selection, the observed inferences will be considered trends or dispositions towards behaviors and results are limited to the investigated sample, without the intention to generalize the population.

\subsection{Operational definition of variables}

In the present study, the Dark Triad is the independent variable, for being able to explain or predict the dependent variable - opportunistic decision-making. 
The operationalization of the independent variable was carried out by comparing it to the factors of the psychological measurement instrument, according to the studies in this issue (Paulhus \&Williams, 2002; Jones \& Paulhus, 2014; Major, 2014; Giammarco, Atkinson, Baughman, Veselka, \& Vernon, 2013).

The dependent variable was operationalized based on the verification of the reflection of the decisions regarding the provision or not to manipulate results, as shown by studies using this approach (Murphy, 2012; Shafer \& Wang, 2011).

The research design is structured in Figure 1, showing the relationship between the conceptual and operational variables of the study variables, as the model of Libby, Bloomfield and Nelson (2002):

Figure 1:

Model of predictive validity of the variables

\begin{tabular}{c|c|c|c|}
\cline { 2 - 3 } $\begin{array}{c}\text { Conceptual } \\
\text { Issue }\end{array}$ & $\begin{array}{l}\text { Independent Construct: } \\
\text { Dark Triad: psychological } \\
\text { traits of narcissism, } \\
\text { machiavellianism and } \\
\text { psychopathy }\end{array}$ \\
\cline { 2 - 3 } $\begin{array}{c}\text { Operational } \\
\text { Issue }\end{array}$ & $\begin{array}{l}\text { Independent Variable: } \\
\text { Psychological Measure } \\
\text { Instrument Factors. } \\
\text { (D3-Short) }\end{array}$ & $\begin{array}{l}\text { Dependent Con struct: } \\
\text { Application of opportunistic } \\
\text { decision-making issues, } \\
\text { operationalized by the points of the } \\
\text { Likert scale }\end{array}$ \\
\hline
\end{tabular}

Source: elaborated by author

The connections between the conceptual and operational variables nurture the verification of whether or not the Dark Triad's personality traits influence or are related to operational opportunistic decision-making.

\subsection{Results}

We learn from Table 1 that the groups consist of different sizes and that there are differences between the averages, according to the levels of personality traits under study. Narcissism showed the highest average of the three traits - 3,0195 - on a scale from 1 to 5 .

Table 1: Descriptive statistics

\begin{tabular}{|c|c|c|c|c|}
\hline Personality Traits & Minimum & Maximum & Mean & $\begin{array}{c}\text { Standard } \\
\text { Deviation }\end{array}$ \\
\hline Machiavellianism & 1.00 & 4.0 & 2,9560 & 0.54354 \\
Narcissism & 2.11 & 4.0 & 3.0195 & 0.39452 \\
Psychopathy & 1.00 & 3,56 & 2.0619 & 0.47684 \\
\hline
\end{tabular}

Source: research data

Regarding the correlation between the personality traits of the Dark Triad, Jones and Paulhus (2014) found a moderate correlation between Machiavellianism and psychopathy $r=0.37$, followed by 
narcissism and Machiavellianism $r=0.23$ and narcissism and psychopathy $r=0.20$. They found that the three traits have the unpleasant behavior in the social environment in common.

Similarly, the study sample showed a significant correlation between the traits of psychopathy and Machiavellianism $r=0.28$; followed by narcissism and Machiavellianism $r=0.25$ and narcissism and psychopathy $r=0.18$. When comparing the results of the two studies, it is possible to confirm greater overlap between Machiavellianism and psychopathy traits.

These results corroborate the idea that, although all the traits have an insensitive nucleus that encourages interpersonal manipulation (Jones and Paulhus, 2009), and are moderately positively correlated, they are conceptually distinct (Paulhus and Williams, 2002; Jones and Paulhus, 2014), which justifies the theoretical and empirical separation for studies that address this issue (O'Boyle et al., 2012).

Table 2: Pearson correlation: Dark Triad (Paulhus, 2013) x Sample under study

\begin{tabular}{|lccc|ccc|}
\hline & \multicolumn{3}{c|}{ Results (Paulhus, 2013) } & \multicolumn{3}{c|}{ Results (Sample under study) } \\
Psychopathy & Narcissism & Machiavellianism & Psychopathy & Narcissism & Machiavellianism \\
$P^{*}$ & 1 & $0.20^{* * *}$ & $0.37^{* * *}$ & 1 & $0.18^{* *}$ & $0.28^{* * *}$ \\
$N^{*}$ & $0.22^{* * *}$ & 1 & $0.23^{* * *}$ & $0.18^{* *}$ & 1 & $0.25^{* * *}$ \\
$\mathrm{M}^{*}$ & $0.37^{* * *}$ & $0.23^{* * *}$ & 1 & $0.28^{* * *}$ & $0.25^{* * *}$ & 1 \\
& & & & & & \\
\hline
\end{tabular}

Note: $P^{*}$-Psychopathy; $N^{*}$-Narcissism; $M^{*}$-Machiavellianism *** Significant at $0.01,{ }^{* *}$ Significant at 0.05 Source: research data

According to Table 3, there is a significant correlation (Pearson $r=0.297, p<0.01$ ) between the Dark Triad independent variable and the opportunistic decision-making dependent variable

This result allows the inference that there is a significant relationship between high traits of the Dark Triad and the opportunistic decision making, in the investigated sample, thus enabling the first statistical confirmation of the hypothesis formulated in this study. It also corroborates previous studies that relate the Dark Triad traits to attitudes of corporate fraud (Johnson et al, 2013; Rijsenbilt \& Commandeur, 2013; Murphy, 2012; McCormick \& Burch, 2005; Clarke, 2005, among others).

Furthermore, the findings confirm the basic theory of this study, namely, that personality influences the interpretations of individuals and, consequently, affects their choices (Hambrick and Mason, 1984).

Table 3: Dark Triad Factor and Decision-making Correlation

\begin{tabular}{|r|c|}
\hline & Opportunistic Decision Making Average \\
\hline Dark Triad Factor & $0.297^{* * *}$ \\
& 0.000 \\
$\mathrm{~N}$ & 131 \\
\hline
\end{tabular}

***The correlation is significant at the 0.01 level (2 extremities). Source: research data 
We applied the ANOVA statistical method with one factor, in order to test the variability of the sample and to verify the difference between the opportunistic decision-making and the three levels of the dark triad.

According to Table 4 , the $F$ test value is 6.171 and $p=0.003$, which suggests that there is a difference in decision making between individuals, according to the classifications adopted in this study for the levels (low, moderate and high) of the Dark Triad. This finding enables the confirmation of the second hypothesis formulated in this study.

Table 4: ANOVA

\begin{tabular}{|c|c|c|c|c|c|}
\hline & Sum of Squares & Df & Medium Square & Sig. \\
\hline Between groups In groups Total & 6.652 & 2 & 3.326 & 6.171 & $0.003^{* * *}$ \\
& 68.992 & 128 & 0.539 & \\
& 75.644 & 130 & & \\
\hline
\end{tabular}

*** Significant at 0.01 .

Source: research data

In order to compare, in pairs, each level of the Dark Triad, with all possible combinations of the groups under analysis, it was observed through the Bonferroni test (post hoc test) that there is a significant difference (sig. $<0.01$ ) between the decision-making of individuals with high and low traits of the Dark Triad, which corroborates the results previously found.

Table 5: Post Hoc Test

\begin{tabular}{|c|c|c|c|c|}
\hline \multirow{2}{*}{$\begin{array}{c}\text { Dependent variable } \\
\text { Opportunistic Decision } \\
\text { Making }\end{array}$} & Dark Triad Classification (I) & (J) Dark Triad Classification & Average difference (I-J) & Sig. \\
Average & Low trait & Moderated & -.13961 & 1.000 \\
Bonferroni & Moderated & High trait & -.53398 & $0.003^{* * *}$ \\
\cline { 2 - 5 } & & Low trait & .13961 & 1.000 \\
& High trait & -.39437 & $0.41^{* *}$ \\
\cline { 2 - 5 } & High trait & Low trait & .53398 & $0.003^{* * *}$ \\
& & Moderated & .39437 & $0.41^{* *}$ \\
\hline
\end{tabular}

Note: *** Significant at $0.01 ; * *$ Significant at 0.05

By analyzing subsets of groups that have the same average (Field, 2009), we also applied the Tukey test (post hoc test). We observed that the low and moderate levels are in the same group and the high one is different from the others, with the higher average.

The graph below illustrates the interaction between the level of traits and the opportunistic decision-making. 


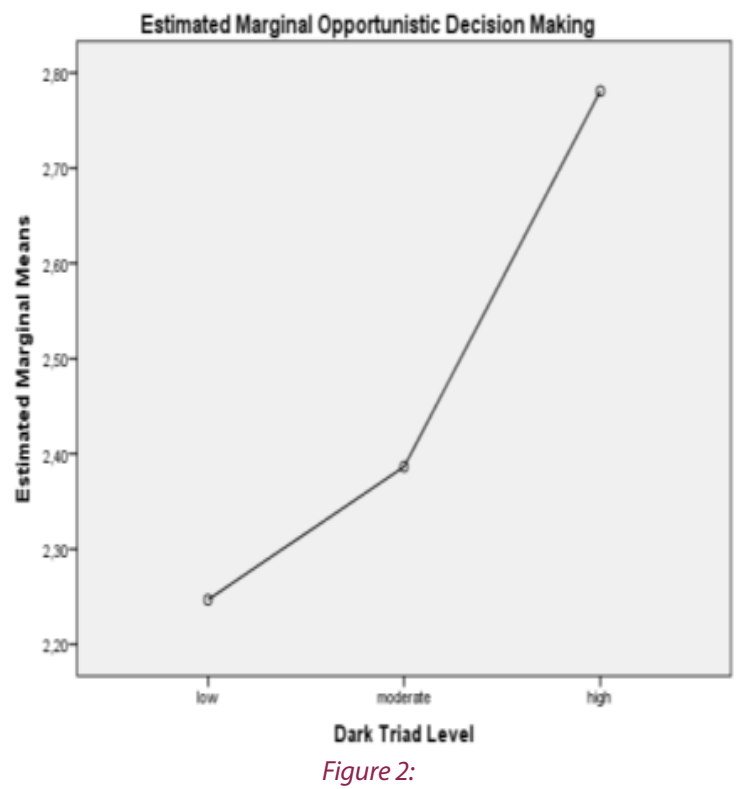

Interaction between the Dark Triad Factor and the Opportunistic Decision-Making

Source: research data

The graph allows for illustrative visualization of the differences between the levels and reinforces our research hypothesis that high traits of the three dark personalities are evidence of higher propensity to opportunistic decision making.

Statistical techniques and the literature review allowed the interpretation of the results, and contributed to the answer to the research issue, as well as the validation of the assumptions made herein.

\section{CONCLUSION}

Business results reflect the performance of CEOs. Disclosure of accounting reports showing gains, on a quarterly and yearly basis, creates consistent opportunities for recognition of business success, whose reflection promote the senior executives and asserts their inflated sense, given the compliments and applauses after a good performance (Olsen et al., 2013). If the association of corporate result to the CEO is something apparently beneficial, it may also prove harm to the organization.

Leaders with socially aversive personality traits, lack of guilt, impulsiveness, insensitivity and need for power can manipulate accounting information to promote the company and themselves in the market. However, understanding how these traits are reflected in the work environment favors the development of preventive measures and/or the knowledge of the attitudes and tactics used by them to persuade and explore colleagues, in order to achieve their personal goals.

Trying to answer the research question of this study - whether individuals with high personality traits of the Dark Triad are inclined to opportunistic decision-making - we developed an empirical-theoretical research, with the application of a self-report questionnaire to $131 \mathrm{MBA}$ students who hold or have already held a managerial position in a company. 
Empirical evidence suggests that respondents with high traits of the Dark Triad are significantly associated to the disposition to opportunistic decision-making. This evidence confirms the non-pathological, manipulative, controlling, unethical and amoral behavior of Machiavellian individuals; the sense of grandiosity, need for admiration and power of the narcissistic individuals; and the selfishness, insensitivity, lack of guilt, shame or remorse about the possible consequences of the decisions of psychopathic individuals. Moreover, it confirms the theory that the personalities of the individuals influence their interpretations and affect their choices.

The results also suggest that there are significant differences in opportunistic decision-making between individuals, according to the classifications adopted in this study for the (low, moderate and high) levels of the Dark Triad. We infer, therefore, that individuals with low and moderate traits of the three dark personalities are less willing to make decisions, as opposed to those who develop high traits.

Individuals with low traits of the Dark Triad do not externalize aversive behaviors, and therefore are less willing to make opportunistic decisions. The moderate traits of the Dark Triad externalized attitudes more similar to those of the low traits. These results encourage future research to investigate whether individuals who have moderate traits of each dark personality are able to make more honest decisions and promote the success of the company.

In this perspective, this study achieved the desired goal, validated the elaborated assumptions and drew the attention of the scientific community to the potential of the Dark Triad in the business field, especially by observing the behavior of managers in the work environment.

This research does not suggest a diagnosis of personality, because we cannot say that the levels and types of personality will be long lasting in all situations and timelines; yet, it signals the importance of checking how psychopathic individuals arrive to higher executive positions, how the impulsivity and self-confidence of narcissistic and Machiavellian managers can leverage the business or even how the Dark Triad traits may, in some circumstances, boost the gain and the social and economic potential of managers and the company. 
American Psychiatric Association. (2000). Diagnostic and statistical manual of mental disorders (4th ed., Rev. ed.).Washington, DC: American Psychiatric Association.

Amernic, J. H. \& Craig, R.J. (2010).Accounting as a facilitator of extreme narcissism. Journal of Business Ethics, 96(1), 79-93.

Arjoon, S. (2010): Narcissistic Behavior and the Economy:The Role of Virtues. Journal of Markets \& Morality, 13(1), 59-82.

Aziz, A., May, K., Crotts, J. C. (2002). Relations of Machiavellian Behavior with Sales Performance of Stockbrokers. Psychological Reports, 90, 451-460.

Babiak, P. \& Hare, R.D. (2006). Snakes in suits: when psychopaths go to work. New York: Harper Collins Publishers Inc.

Babiak, P., Neumann, C. \& Hare R.D. (2010). Corporate psychopathy: talking the walk. Behavioral Sciences and the Law, 28(2), 174-193.

Bazerman, M. H. \& Moore, D. A. (2010). Processo decisório. Elsevier.

Beneish, M. D. (2001),"Earnings management: a perspective". Managerial Finance. 27(12), 3 - 17 Available in: http://dx.doi.org/10.1108/03074350110767411

Boddy, C. R. (2005).The Implications of Corporate Psychopaths for Business And Society: An initial examination and a call to arms. Australasian Journal of Business and Behavioral. 1(2).

Boddy, C.R. (2006). The dark side of management decisions: organizational psychopaths. Management decision, 44(10), 1461-1475.

Boddy, C. R. (2010). Corporate Psychopaths and organizational type. Journal of Public Affairs.10, 300-312.

Bonner, S. E. (2007). Judgment and decision making in accounting. Upper Saddle River, N.J: Prentice Hall.

Byington, J. R. \& Johnson, G., (1990). Machiavellianism and Accounting Competence: Effects on Budgetary Attitudes. Journal of Applied Business Research, 98- 104.

Campbell, W.K., Goodie, A.S. \& Foster, J.D. (2004). Narcissism, confidence, and risk attitude. Journal of behavioral decision making, 17, 297-311. 
Campbell, W. K., Hoffman, B. J., Campbell, S. M. \& Marchisio, G. (2011). Narcissism in organizational contexts. Human Resource Management Review, 21(4), 268-284.

Chatterjee, A. \& Hambrick. D. C. (2007). It's all about me: narcissistic chief executive officers and their effects on company strategy and performance. Administrative science quarterly, 52(3), 351-386.

Cervone, D., \& Pervin, L.A. (2008). Personality:Theory and research (10th ed.). New York: John Wiley and Sons.

Christie, R. \& Geis, F.L. (1970). Studies in Machiavellianism. New York: Academic Press.

Clarke J. (2005). Working with Monsters. How to identify and protect yourself from the workplace psychopath, Random House, Sydney.

Corzine, J. B. (1997). Machiavellianism and management: a review of single-nation studies exclusive of the USA and cross-national studies. Psychological Reports, 80(1), 291-304.

Crysel, L.C., Crosier, B.S., Webster, G.D. (2013). The dark triad and risk behavior. Personality and individual differences.54, 35-40.

Deutschman, A. (2005). Is your boss a psychopath? Fast Company.

Dworkis, K. (2013).The interactive effects of incentive threshold and narcissism on managerial decision-making. Dissertation, University of Southern California, Los Angeles, California. Available in: http:// digitallibrary.usc.edu/cdm/ref/collection/p15799coll3/id/129532.

Edwards, W. (1954).The theory of decision making. Psychol. Bulletin, 51: 380-417.

Fehr, B., Samsom, D. \& Paulhus, D. L. (1992). The construct of machiavellianism: twenty years later. In C. D. Spielberger \& J. N. Butcher (Eds.). Advances in personality assessment, 9, 77-116. Hillsdale, NJ: Erlbaum

Field, A. (2009). Descobrindo a estatística usando o SPSS. Porto Alegre: Artmed.

Furnham, A. Richards, S. C. \&Paulhus, D. L. (2013). The Dark Triad of Personality: A 10 Year Review. Social and Personality Psychology Compass, 7(3), 199-216.

Giammarco, E.A., Atkinson, B., Baughman, H.M., Veselka, L. \&Vernon, P. A. (2013).The relation between antisocial personality and the perceived ability to deceive. Personality and Individual Differences, 54, $246-250$.

Goldberg, L. R. (1999). A broad-bandwidth, public-domain, personality inventory measuring the lower-level facets of several five-factor models. In I. Mervielde, I. J. Deary, F. DeFruyt, \& F. Ostendorf (Eds.). Personality psychology in Europe, 7, 7-28. Tilburg University Press. 
Hambrick, D. C. \& Mason, P. A. (1984). Upper echelons: The organization as a reflection of its top managers. Academy of Management Review, 9, 193-206.

Hartmann, F.G.H. \& Maas, V.S. (2010). Why business unit controllers create budget slack: involvement in management, social pressure, and machiavellianism. Behavioral research in accounting: Fall, 22(2), 27-49.

Hogan, R. (2007). Personality and the fate of organizations. Mahwah, NJ, US: Lawrence Erlbaum Associates Publishersix, 167.

Hurst, C., \& Jung, Y. (n.d.).Using Personality Assessment for Management and Leadership Development: An Overview. Available in: http://www.lib.uwo.ca/files/business/Personality_NoteHurst.pdf.Accessed: March 3, 2013.

Jain, Kriti\& Bearden, J. N. (2011). Machiavellianism and Overconfidence. [Working Paper].Insead - the Business School for the world.

Johnson, E.N., Kuhn, J.R. Jr, Apostolou, B. \& Hassell, J.M. (2013). Auditor perceptions of client narcissism as a fraud attitude risk factor. Auditing: a journal of theory \& practice, 32 (1), 203-219.

Jones, D.N. (2013). Psychopathy and machiavellianism predict differences in racially motivated attitudes and their affiliations. Journal of applied social psychology, 43, 367-378.

Jones, D.N. \& Paulhus D.L. (2009). Machiavellianism. In: Leary, M.R., Hoyle, R.H. (Eds.). Individual differences in social behavior. New York: Guilford, 93-108.

Jones, D.N. \& Paulhus, D.L. (2014).Introducing the short dark triad (SD3): A brief measure of dark personality traits. Assessment, 21(1) 28-41.

Judge, T.A., Piccolo, R.F. \& Kosalka, T. (2009). The bright and dark side of leader traits: a review and theoretical extension of the leader trait paradigm. The leadership quarterly, 20(6), 855-875.

Kahneman, D. \&Tversky, A. (1974). Judgment under uncertainty: heuristics and biases. Science, New Series, 185(4157), 1124-1131.

Kiazada, K., Restubog, S. L. D., Zagenczyk, T. J., Kiewitz, C. \& Tang, R. L. (2010) In pursuit of power: The role of authoritarian leadership in the relationship between supervisors' Machiavellianism and subordinates' perceptions of abusive supervisory behavior. Journal of Research in Personality, 44, 512-519.

Lakey, C.E., Rose, P., Campbell, W. K. \& Goodie, A.S. (2008). Probing the Link between Narcissism and Gambling: The Mediating Role of Judgment and Decision-Making Biases. Journal of behavioral decision making, 21, 113-137. 
Levy, K. N., Reynoso, J. S., Wasserman, R. H. \&Clarkin, J. F. Transtorno de personalidade narcisista. In: O`Donohue, W., Fowler, K. A. \&Lilienfeld, S. O. (Orgs). Transtorno de personalidade em direção ao DSM-V. (2010). São Paulo: Roca, 2010. Trad. Fábio Moraes Corregiari.

Libby, R., Bloomfield, R. \& Nelson, M. W. (2002).Experimental research in financial accounting. Accounting, Organizations and Society, 27, 775-810.

Maccoby, M. (2004). Narcissistic leaders: the incredible pros, the inevitable cons. The harvard business review.

Mchoskey, J. (1995). Narcissism And Machiavellianism. Psychological Reports, 77, 755-759.

Majors, T.M. (2014). Communicating measurement uncertainty: an experimental study of financial reporting implications for managers and investors. [Working paper]. Available at SSRN: http://ssrn.com/ abstract=2390102 or http://dx.doi.org/10.2139/ssrn.2390102.

Maleki, M. (2013). Narcissism and Decision-Making Styles Principals. Asian Journal of Research in Social Sciences and Humanities, 3(10), 359-370.

McCormick, I. \& Burch, G. (2005). Corporate behavior; snakes in suits - fear and loathing in corporate clothing; they're glib, charming, deceitful and ruthless; they've been described as 'snakes in suits' - and they're in an office near you", New Zealand Management, 34.

Mohanran, P.S. (2003). How to manage earnings management. Accounting World, 13-19.

Murphy, P.R. (2012). Attitude, Machiavellianism and the rationalization of misreporting. Queen's University School of Business Research Paper.

Nars, K. (2012). Golpes Bilionário\$: Como os maiores golpistas do mundo enganaram tanta gente por tanto tempo. Trad. Lilian Loman e Pasi Loman. Belo Horizonte, Gutenberg.

O'Boyle, E.H., Jr., Forsyth, D.R., Banks, G.C. \& Mc Daniel, M.A (2012). A meta-analysis of the dark triad and work behavior: a social exchange perspective. Journal of applied psychology, 97(3), 557-579.

O'Reilly, C. A. Doerr, B., Caldwell, D. F. \& Chatman, J.A. (2013). Narcissistic CEOs and Executive Compensation. [Working Paper Series].The Leadership Quarterly, Available in: http://dx.doi.org/10.1016/j.leaqua.2013.08.002.

Ouimet, G. (2010). Dynamics of narcissistic leadership in organisations: towards an integrated research model. Journal of Managerial Psychology, 25(7), 713-726.

Olsen, K.J., Young, S.M. \& Dworkis, K. (2013). CEO narcissism and accounting: A picture of profits. Journal of management accounting research, In-Press. 
Patrick, C. (2010). Transtorno de personalidade antissocial e psicopatia. In: O`Donohue, W., Fowler, K. A. \&Lilienfeld, S. O. (Orgs). Transtorno de personalidade em direção ao DSM-V. (2010). São Paulo: Roca, 2010. Trad. Fábio Moraes Corregiari.

Paulhus, D. L. (2013). Dark Triad of Personality (D3-Short). Measurement Instrument Database for the Social Science. Retrieved from www.midss.ie.

Paulhus, D.L. \&Williams, K. (2002).The dark triad of personality: narcissism, machiavellianism, and psychopathy. Journal of research in personality, 36, 556-563.

Pech, R.J., \& Slade, B.W. (2007).Organisational sociopaths: rarely challenged, often promoted. Why? Society and Business Review, 2(3), 254-269.

Rijsenbilt, A. \& Commandeur, H. (2013). Narcissus Enters the Courtroom: CEO Narcissism and Fraud. J Bus Ethics, 117, 413-429.

Rosenthal, S. A. \&Pittinsky, T. L. (2006) Narcissistic leadership. The Leadership Quarterly, 17, 617-633.

Shafer, W.E. \&Wang, Z. (2011) Effects of ethical context and machiavellianism on attitudes toward earnings management in China. Managerial auditing journal, 26(5), 372- 392.

Scott, W. R. (2009). Financial accounting theory. 5rd ed. Toronto: Prentice Hall.

Schilit, H. M \& Perler, J. (2010). Financ1al Sh€Nanigan\$. Third Edition. McGraw-Hill E-books.

Simon, H. A. (1970). Comportamento administrativo: estudo dos processos decisórios nas organizações administrativas. (2a ed. Pinto, A. L. trad.). Rio de Janeiro: Fundação Getúlio Vargas.

Stolowy, H. \& Breton, G. (2004). Accounts manipulation: a literature review and proposed conceptual framework. Review of Accounting and Finance. East Yorkshire: 3(1), 5-66.

Smith, S. F. \&Lilienfeld, S. O. (2013) Psychopathy in the workplace: The knowns and unknowns. Aggression and Violent Behavior, 18, 204-218.

Spain, S.M., Harms, P. \& Lebreton, J.M. (2014). The dark side of personality at work. Journal of organizational behavior, 35, 41-60.

Sternberg, R. J. (2010). Psicologia Cognitiva. São Paulo: Cengage Learning.

VandenBos, G. R. (org.). (2010). Dicionário de psicologia da American Psychological Association. Trad. Daniel Bueno, et al. Porto Alegre: Artmed, 1040 p. 